\title{
Relationship between ABO Blood Group and COVID-19: The Case of Siirt
}

\author{
ABO Kan Grubu ve COVID-19 Arasındaki ilişki: Siirt Örneği
}

\author{
(D) Mehmet ÜYÜKLÜ1, iD Osman ÖZÜDOĞRU22 \\ 1Siirt University Faculty of Medicine, Department of Physiology, Siirt, Turkey \\ 2Siirt State Hospital, Clinic of Internal Medicine, Siirt, Turkey
}

\begin{abstract}
Objective: Epidemiological and clinical studies have shown that age and chronic diseases are important risk factors in the mortality of patients infected by Coronavirus disease 2019 (COVID-19). However, there is no biomarker identified yet for susceptibility to the disease. Some studies have reported that $\mathrm{ABO}$ blood groups are associated with a predisposition to Covid-19. In this study, it was aimed to investigate the relationship between $\mathrm{ABO}$ blood groups and COVID-19 susceptibility in Siirt province scale.
\end{abstract}

Methods: In this study, the blood groups of 174 patients, all of whom were in Siirt, were confirmed retrospectively at the Siirt State Hospital, all confirmed by revers-transcriptase chain reaction. For comparison, data from 36394 patients whose blood group was detected in the Siirt State Hospital were used.

Results: In Siirt provincial normal population; while blood groups $\mathrm{A}, \mathrm{B}, \mathrm{AB}$ and $\mathrm{O}$ were $40 \%, 19.5 \%, 8.5 \%$ and $32 \%$ respectively, the blood groups of COVID-19 positive patients were $42.5 \%, 19.5 \%$, $8 \%$, and $30 \%$. No statistically significant difference was found in blood group distribution rates between healthy and COVID-19 patient groups $(>0.05)$. The distribution of blood group rates of patients hospitalized in the intensive care unit was not different from healthy individuals $(>0.05)$. No significant difference could be calculated between the duration of hospitalization in the intensive care unit and blood groups.

Conclusion: As a result, unlike studies showing that the risk of COVID-19 infection was higher in the A blood group and lower in the $\mathrm{O}$ blood group, no relationship was found between the

\section{ÖZ}

Amaç: Epidemiyolojik ve klinik çalışmalar, Coronavirus hastalığı 2019 (COVID-19) ile enfekte olan hastaların mortalitesinde yaş ve kronik hastalıkların önemli risk faktörü olduğunu göstermiştir. Bununla birlikte hastalığa yatkınlık için henüz tanımlanmış bir biyolojik belirteç bulunmamaktadır. Yapılan bazı çalışmalar $\mathrm{ABO}$ kan gruplarının COVID-19'a yatkınlıkla ilişkili olduğu bildirmiştir. Bu çalışmada Siirt il ölçeğinde ABO kan grupları ile COVID-19 yatkınlığı arasındaki ilişkinin araştııılması amaçlanmıştır.

Yöntemler: Bu çalş̧mada Siirt Devlet Hastanesinde tümü gerçek zamanlı polimeraz zincir reaksiyonu ile doğrulanmış tamamı Siirt'li olan 174 hastanın kan grupları retrospektif olarak değerlendirilmiştir. Karşıllaştırma için Siirt Devlet Hastanesinde kan grubu tespiti yapılan 36.394 hastaya ait veriler kullanılmıştır.

Bulgular: Siirt il geneli normal popülasyonda; A, B, AB ve O kan grupları sirasıla $\% 40, \% 19,5, \% 8,5$ ve $\% 32$ iken COVID-19 pozitif hastaların kan grupları sırasıla; $\% 42,5, \% 19,5, \% 8, \% 30$ bulunmuştur. Sağılklı ve COVID-19 hasta grupları arasında kan grubu dağılım oranları arasında istatistiksel olarak anlamlı bir fark bulunmamıştır $(>0.05)$. Yoğun bakım ünitesinde yatan hastaların kan grubu oranlarındaki dağılım da sağlıklı bireylerden farklı bulunmamıștır $(>0.05)$. Yoğun bakımdaki yatış süresi ile kan grupları arasında da anlamlı bir fark hesaplanamamışıtır.

Sonuç: Sonuç olarak, COVID-19 enfeksiyonu riskinin A kan grubunda daha yüksek, 0 kan grubunda daha düşük olduğunu gösteren çalışmaların aksine kan grubuyla COVID-19 enfeksiyon riski ve yoğun bakım tedavisi arasında bir ilişki bulunmamıştır. Bu

Address for Correspondence: Mehmet ÜYÜKLÜ, Siirt University Faculty of Medicine, Department of Physiology, Siirt, Turkey

E-mail: mmuyuklu@gmail.com ORCID ID: orcid.org/0000-0002-7100-9817 
blood group and the risk of COVID-19 infection and intensive care therapy. Combining the results of this study with data from other regions, it is thought that only if the relationship between blood group COVID-19 can be confirmed, it may be a guide for diagnosis, follow-up and treatment.

Keywords: COVID-19, blood group, corona virus, Siirt çalışmadaki sonuçların, diğer bölgelerdeki verilerle birleştirilmesiyle kan grubu COVID-19 arasındaki ilişki doğrulanabildiği takdirde ancak tanı, takip ve tedaviye yol gösterici olabileceği düşünülmektedir.

Anahtar Sözcükler: COVID-19, kan grubu, korona virus, Siirt

\section{Introduction}

The new Coronavirus disease (COVID-19) infection appeared in Wuhan, China in December 2019. Cases of pneumonia associated with this virus have spread rapidly since then and affected many countries and regions with large epidemics $(1,2)$. Clinical studies have shown that the most common symptoms of COVID-19 are fever, fatigue and dry cough. Other symptoms are myalgia, chest tightness, shortness of breath, nausea, vomiting, and diarrhea. In thoracic computed tomography scans, multiple bilateral ground glass opacities/consolidation are observed as typical viral pneumonia images (3). Common laboratory findings are lymphopenia and/or leukopenia. No specific therapeutic agent has been available for corona virus infections to date. However, various approaches are used for treatment but there is not yet a defined biomarker for susceptibility to the disease.

Blood type is used for antigens made by various gene alleles on red blood cells and it is reported that there are more than 400 antigens on the erythrocyte (4). In 1901, Karl Landsteiner discovered the $\mathrm{ABO}$ system, which contains 4 main blood groups $\mathrm{A}, \mathrm{B}, \mathrm{AB}$ and $\mathrm{O}$ (5). $\mathrm{ABO}$ antigens are carbohydrate moieties expressed on red blood cells as well as other cells and tissues and represent the main determinants of blood transfusion compatibility. $\mathrm{ABO}$ antigens are commonly expressed in epithelial cells, sensory neurons, body fluids, including platelets and endothelium of blood vessels, and cell surfaces in tissues in addition to erythrocytes (6). In connection with the widespread distribution of these antigens, it is said that some diseases may be associated with $\mathrm{ABO}$ blood types. It has been reported that plasma Willebrand factor, Factor VIII, total cholesterol, cardiovascular diseases and malaria (malaria) are observed more frequently in people other than those with 0 blood type (710). Some studies have reported that $A B O$ blood types are also associated with susceptibility to COVID-19. In these studies, it was found that the risk of COVID-19 infection was higher in blood type A and lower in blood type 0 (11-13). In this study, it was aimed to investigate the relationship between $\mathrm{ABO}$ blood types and COVID-19 susceptibility in Siirt provincial scale.

\section{Material and Method}

\section{Patient Population}

The study group consisted of 174 patients from Siirt, who had a diagnosis of COVID-19 made in Siirt State Hospital, who were confirmed as positive with revers-transcriptase chain reaction, who were $\geq 18$-year-old male and non-pregnant female. Patients' gender, age, intensive care and death, length of stay in intensive care, their average age and lymphocyte, D-dimer, C-reactive protein (CRP) and ferritin parameters of intensive care patients were evaluated. Again, the blood types of the same patients and the results of 36394 people, all of whom were from Siirt (including districts) and whose blood groups were evaluated in Siirt State Hospital between 2015 and 2020, as the control group were used. The whole study was conducted retrospectively. For the study, approval was obtained from The Chief Physician of Siirt State Hospital, Siirt University non-Invasive Clinical Research Ethics Board (2020/8:03) and the Republic of Turkey Ministry of Health, Health Services Directorate General, Scientific Research Platform on 5/28/2020 (2020-05-22-T21_49_16).

\section{Statistical Analysis}

Results are given as mean \pm standard error. Statistical comparisons between the groups were evaluated by the "Chi-square $\left(\chi^{2}\right)$ " and "Student's t-test", and intergroup comparisons of the variables were performed with the one-way analysis of variance (ANOVA). $P$ values less than 0.05 were considered statistically significant. (PRISM 6.0, GraphPad Software, Inc., La Jolla, CA, USA).

\section{Results}

According to the brochure prepared by the Red Crescent Society of Turkey, about $45 \%$ of people in Turkey have blood type A, 16\% have blood type $\mathrm{B}, 6 \%$ have blood type $\mathrm{AB}$ and $33 \%$ have blood type $\mathrm{O}$. The blood types $\mathrm{A}, \mathrm{B}, \mathrm{AB}$, and $\mathrm{O}$ of normal population in the province of Siirt were found to be $40 \%, 19.5 \%, 8.5 \%$ and 32\%, respectively. The blood types of COVID-19 patients in Siirt State Hospital were 42.5\% (A), 19.5\% (B), 8\% (AB), and $30 \%(\mathrm{O})$ (Table 1). The comparison of the overall results of Siirt and Turkey revealed regional differences. It was observed that the blood type A was lower than the normal distribution in the province of Siirt, but the B and AB blood types were higher (Table 1).

79 of the patients from Siirt, who had a definite diagnosis of COVID-19 positive, were male (M: 45.4\%), and 95 of them were female (F: 54.6\%). The mean ages of the patients were calculated as 44.90 and 43.23, respectively, and no significant difference was found between them ( $p>0.05) .28$ of the patients were hospitalized in intensive care unit (M: 16, F: 12) and 16 died (M: 8, F: 8). The average age of the patients hospitalized in intensive care unit was calculated as 60.94 years for males and 72.92 years for females, and the mean age of those who died was calculated as 62.50 years for males and 76.80 for females. It was 
observed that the average age of both patients being hospitalized in the intensive care unit and those who died was lower in men than in women $(\mathrm{p}<0.05$, Table 2$)$. Almost all patients in the intensive care unit have a similar clinical Picture. In 27 patients, lymphocyte value was less than 800 (Lymphopenia), D-dimer value was higher than $1000 \mu \mathrm{g} / \mathrm{L}$ and CRP was higher than 40 $\mathrm{mg} / \mathrm{L}$. In 25 patients, ferritin value was measured to be higher than $500 \mu \mathrm{g} / \mathrm{L}$.

Table 3 compares the blood groups of COVID-19 positive $(n=174)$ and control groups $(n=36394)$. The susceptibility of the A blood group to COVID-19 infection, compared to the other blood groups, changed 1,096 times ( $p>0.05$ ); the susceptibility of the blood group $\mathrm{O}$ to COVID-19 infection changed 0.910 times ( $\mathrm{p}>0.05)$. Blood groups of $\mathrm{A}, \mathrm{B}, \mathrm{AB}$ and $\mathrm{O}$ in patients receiving intensive care treatment were $43 \%, 17 \%, 7 \%$ and $33 \%$, respectively. It was calculated that the intensive care risk in blood type A changed 1,133 times ( $p>0.05)$ and in blood group $\mathrm{O}$, it changed 1.068 times $(\mathrm{p}>0.05)$.

No significant change was calculated in other blood types. As a result of the statistical analysis, no significant difference was found in the comparison of blood groups between the two groups $(p>0.05)$. A similar comparison was made for patients hospitalized in the intensive care unit and again, no difference was observed in terms of blood types ( $>>0.05$, Table 3$)$. The relationship between the length of stay of the patients in the intensive care unit and their blood groups is shown in Table 3. The length of stay in the intensive care unit (days) is as follows, from the highest to the lowest, respectively: A (11.53 \pm 4.05$)$, $\mathrm{O}(9.30 \pm 5.75), \mathrm{B}(7.00 \pm 5.05)$ and $\mathrm{AB}(6.00 \pm 7.07)$. Although patients with blood type A had the longest length of stay in the intensive care unit, no statistically significant difference was found in the comparison of variables between the groups $(\mathrm{p}>0.05)$.

\section{Discussion}

In the early stage, the coronavirus primarily targets the respiratory system and reproduces. It uses the angiotensin converting enzyme receptor to enter the cell (14-16). These receptors are predominantly found in the lung, small intestine, and vascular endothelial cells. It has been shown that IL-2, IL-6, CRP, Ferritin, D-dimer and Troponin levels increase and lymphopenia is observed in patients with a severe course of COVID-19 (1417). In the results of our study, an increase in CRP, Ferritin, and $\mathrm{D}$-dimer levels and lymphopenia were observed in patients hospitalized in the intensive care unit (Table 2).

Apart from erythrocytes, $\mathrm{ABO}$ antigens are also found on the cell surfaces of many tissues, especially in epithelial cells, sensory neurons, platelets and endothelium of blood vessels (6). Many studies have evaluated that $\mathrm{ABO}$ blood groups may be associated

Table 1. Comparative distribution of Siirt, COVID-19 positive and Turkey's blood types (\%).

Distribution of blood types

\begin{tabular}{|l|l|l|l|l|}
\hline & A & B & AB & O \\
\hline Siirt (control) & $40,3 \%$ & $19,34 \%$ & $\mathbf{8 , 4 7 \%}$ & $31,88 \%$ \\
$(n=36394)$ & $(14.666)$ & $(7.038)$ & $(3.086)$ & $(11.604)$ \\
COVID-19 & $42,53 \%$ & $19,54 \%$ & $8,05 \%$ & $29,88 \%$ \\
$(n=174)$ & $(74)$ & $(34)$ & $(14)$ & $(52)$ \\
\hline Turkey* & $45 \%$ & $16 \%$ & $6 \%$ & $33 \%$ \\
\hline *Source: Red crescent, COVID: Coronavirus disease & & & \\
\hline
\end{tabular}

Table 2. Comparison of the age, gender, intensive care and clinical pictures of COVID-19 positive patients

\begin{tabular}{|c|c|c|c|}
\hline Patients ( $n=174)$ & Male $(n=79) 45.4 \%$ & Female $(n=95) 54.6 \%$ & $\mathrm{p}$ \\
\hline Age (year) & $44.90 \pm 19.9$ & $43.23 \pm 20.51$ & 0.05 \\
\hline Intensive care & $16(20 \%)$ & $12(12,6 \%)$ & \\
\hline Death & $8(10.1 \%)$ & $8(8.4 \%)$ & \\
\hline Mean age for death & $62.5 \pm 15.13$ & $76.8 \pm 5.03^{*}$ & 0.024 \\
\hline \multicolumn{4}{|l|}{ Intensive care patients ( $n=28$ ) } \\
\hline Lymphocyte $(<800)$ & 15 & 12 & \\
\hline D-dimer (>1000 $\mu \mathrm{g} / \mathrm{L})$ & 15 & 12 & \\
\hline $\mathrm{CRP}(>40 \mathrm{mg} / \mathrm{L})$ & 15 & 12 & \\
\hline Ferritine $(>500 \mu g / L)$ & 14 & 11 & \\
\hline
\end{tabular}


with some diseases. It has been reported that plasma coagulation factors (Willebrand factor, Factor VIII), blood lipid levels, cardiovascular diseases and malaria are observed more frequently in people other than $\mathrm{O}$ blood group (7-10). Epidemiological and clinical studies have shown that age and chronic diseases (cardiovascular disease, diabetes, chronic obstructive pulmonary disease, etc.) are important risk factors in the mortality of patients infected by COVID-19. In recent studies, it has been evaluated that there is a relationship between $\mathrm{ABO}$ blood groups and being infected by COVID-19, and the risk of COVID-19 infection is higher in the A blood type and lower in the O blood type (11-13). People with blood type A have been said to have potential risk for COVID-19 infection. In this study we conducted throughout the province of Siirt, no relationship was found between blood groups and COVID-19 infection, hospitalization and length of hospitalization in intensive care unit (Table 3).

In studies stating that blood group $A$ is a risk factor for COVID-19 infection, it is thought that the small number of control group samples used for comparison may not be sufficient to fully compare with the patient population or may not fully reflect the blood group distribution of that population. It is a known fact that the distribution of blood groups is not the same geographically among countries or in different regions of the same country. A similar situation was encountered for the comparison of Turkey with Siirt general population (Table 1). It was observed that the frequencies of $\mathrm{B}$ and $\mathrm{AB}$ blood types were higher in the region, and the frequency of blood type A was lower. It is believed that it was an advantage for our study that all of our COVID-19 positive patients $(n=174)$ and control group samples $(n=36394)$ were from Siirt and the number of control group samples used for comparison was high.

\section{Conclusion}

The $\mathrm{ABO}$ system is found on the surface of platelets, vascular epithelial cells, intestinal, cervical and mammary gland epithelial cells (6). Unlike the ABO system, the Rh system is not found in other tissues except erythrocytes. According to some studies, ABO blood groups may be associated with some diseases, and this relationship has been attributed to the widespread presence of this system in human body tissues and cells. It has been stated that the presence of Rh system only in erythrocytes is excluded from this relationship because approximately $85 \%$ of humans are $\mathrm{Rh}+$. For this reason, only $\mathrm{ABO}$ system data are included in the results section of our study. As a result, unlike studies showing that the risk of COVID-19 infection is higher in blood group A and lower in blood group $\mathrm{O}$, no relationship was found between blood type and the risk of COVID-19 infection and intensive care treatment. The small area of the study indirectly caused the number of patients to be low. It is necessary to investigate and support this relationship with studies involving larger patient series and / or to be confirmed by re-evaluating the results by adding other patients who were not included in this study after the pandemic.

Table 3. Comparison of blood groups in control, COVID-19 positive and intensive care patients

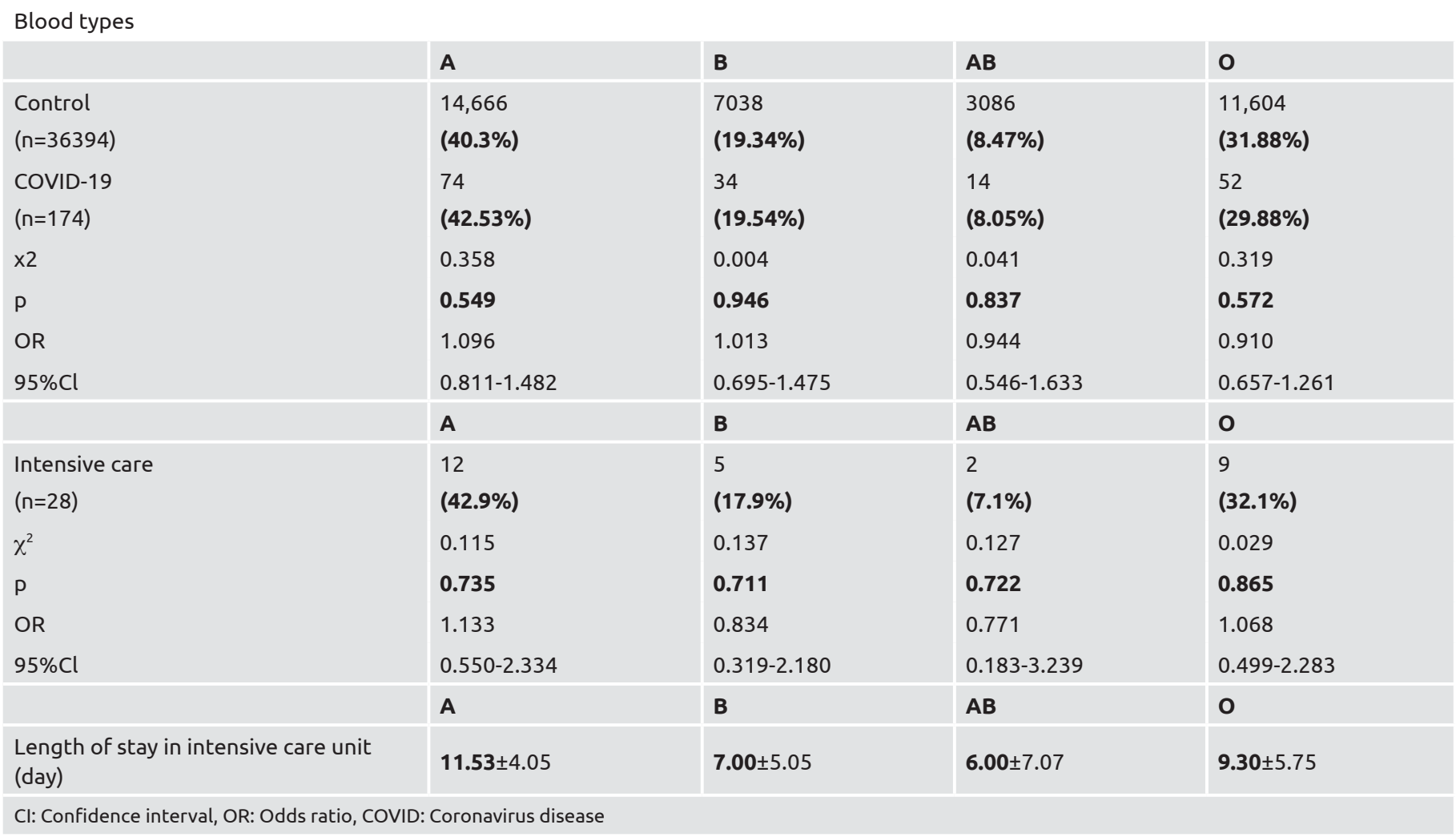




\section{Ethics}

Ethics Committee Approval: The study, approval was obtained from The Chief Physician of Siirt State Hospital, Siirt University non-Invasive Clinical Research Ethics Board (2020/8:03) and the Republic of Turkey Ministry of Health, Health Services Directorate General, Scientific Research Platform on 5/28/2020 (2020-05-22-T21_49_16).

Informed Consent: Informed consent was obtained from all study participants.

Peer-review: Internally peer reviewed.

\section{Authorship Contributions}

Concept: M.Ü., O.Ö., Design: M.Ü., O.Ö., Data Collection or Processing: M.Ü., O.Ö., Analysis or Interpretation: M.Ü., O.Ö., Literature Search: M.Ü., O.Ö., Writing: M.Ü., O.Ö.

Conflict of Interest: No conflict of interest was declared by the authors.

Financial Disclosure: The authors declared that this study received no financial support.

\section{References}

1. Wu F, Zhao S, Yu B, Chen YM, Wang W, Song ZG, et al. A new coronavirus associated with human respiratory disease in China. Nature 2020;579:265-9.

2. Huang C, Wang Y, Li X, Ren L, Zhao J, Hu Y, et al. Clinical features of patients infected with 2019 novel coronavirus in Wuhan, China. Lancet 2020;395:497-506.

3. Chan JF, Yuan S, Kok KH, To KKW, Chu H, Yang J. et al. A familial cluster of pneumonia associated with the 2019 novel coronavirus indicating person-to-person transmission: a study of a family cluster. Lancet 2020;395:514-23

4. Calhoun L, Petz LD. Erythrocyte antigens and antibodies. In: Williams Hematology. Beutler E, Lichtman MA, Coller BS and Kipps TJ (eds) Fifth edition, New York, McGraw-Hill, 1995:1595.

5. Lesky E. Viennese serological research about the year 1900: its contribution to the development of clinical medicine. Bull N Y Acad Med 1973;49:100-11.
6. Eastlund T. The histo-blood group $\mathrm{ABO}$ system and tissue transplantation. Transfusion 1998;38:975-88.

7. Jenkins PV, O’Donnell JS. ABO blood group determines plasma von Willebrand factor levels: a biologic function after all? Transfusion 2006;46:1836-44.

8. Folsom AR, Wu KK, Rosamond WD, Sharrett AR, Chambless LE. Prospective study of hemostatic factors and incidence of coronary heart disease: the Atherosclerosis Risk in Communities (ARIC) Study. Circulation 1997;96:1102-8.

9. Whincup PH, Danesh J, Walker M, Lennon L, Appleby P, Rumley A, et al. von Willebrand factor and coronary heart disease: prospective study and meta-analysis. Eur Heart J 2002;23:1764-70.

10. Chen Y, Chen C, Ke X, Xiong L, Shi Y, Li J, et al. Analysis of circulating cholesterol levels as a mediator of an association between $\mathrm{ABO}$ blood group and coronary heart disease. Circ Cardiovasc Genet 2014;7:43-8.

11. Li J, Wang X, Chen J, Cai Y, Deng A, Yang M. Association between $\mathrm{ABO}$ blood groups and risk of SARS-CoV-2 pneumonia. $\mathrm{Br} \mathrm{J}$ Haematol 2020.

12. Zhao J, Yang Y, Huang H, Li D, Gu D, Lu X, et al. Relationship between the ABO Blood Group and the COVID-19 Susceptibility. MedRxiv 2020.

13. Goker H, Aladag KE, Demiroglu H, Ayaz CM, Buyukasik, Y, Inkaya AC, et al. The effects of blood group types on the risk of COVID-19 infection and its clinical outcome. Turk J Med Sci 2020;50:679-83.

14. Gao J, Tian Z, Yang X. Breakthrough: Chloroquine phosphate has shown apparent efficacy in treatment of COVID-19 associated pneumonia in clinical studies. BioScience Trends 2020;14-1:72-3.

15. Zhou D, Dai SM and Tong Q. COVID-19: a recommendation to examine the effect of hydroxychloroquine in preventing infection and progression. Journal of Antimicrobial Chemotheraphy 2020.

16. Timothy F. Simpson, Richard J. Eric C. Ventricular Arrhythmia Risk Due to Hydroxychloroquine-Azithromycin Treatment for COVID-19. ACC Cardiology Magazine. 2020.

17. Siddiqi HK, Mehra MR. COVID-19 Illness in Native and Immunosuppressed States: A Clinical Therapeutic Staging Proposal. J Heart Lung Transplant. 2020;39:405-7. 